\title{
NUTRITIONAL VALUE AND FATTY ACIDS COMPOSITION IN THE MOST COMMON EGYPTIAN FISH AS AFFECTED BY TRADITIONAL GRILLING PROCESS \\ El-Shehawy, Sh. M. ${ }^{1}$; Gehan A. Goneim ${ }^{1}$ and Zeinab S. Farag ${ }^{2}$ \\ ${ }^{1}$ Food Industries Dept., Fac. Agric., Mansoura University, Egypt \\ ${ }^{2}$ Food Industries Dept., Fac. Agric., Damietta, Mans. Univ., Egypt
}

\begin{abstract}
This research was carried out to study the impact of the traditional grilling process on the nutritional value and fatty acids composition of the most common Egyptian fish (Tilapia, Mullet and Sardine). The obtained results showed a decrease in moisture, ash and oil in grilled fish as a result of grilling process, where crude oil decreased from $22.14 \%$ to $11.40 \%$ (based on dry weight) in Mullet fish. While, crude protein increased from $69.04 \%$ to $86.71 \%$ (based on dry weight) in Mullet fish, too. As for fatty acids composition, decrease percentage of saturated fatty acids were $4.25 \%$ and $2.35 \%$ for Sardine and Tilapia, respectively, while this percentage increased in Mullet fish by $6.25 \%$ of saturated fatty acids. Also, monounsaturated fatty acids percentage decreased in Sardine and Mullet fish by $3.84 \%$ and $11.72 \%$, respectively. Polyunsaturated fatty acids increased in all types of fish by various percentages. Total unsaturated fatty acids/ total saturated fatty acids ratio of fish oils increased in both Sardine and Tilapia, where the rise percentage were $9.76 \%$ and $4.6 \%$, respectively, while decrease percentage of this ratio in Mullet fish was $9.55 \%$. Results of this study has shown that the common Egyptian fish were very poor in polyunsaturated fatty acids content, especially the omega-3 (EPA and DHA). So, it is recommended to increase consumption of other types of fish which are rich in these fatty acids.

Keywords: Fish grilling process, chemical composition, nutritional value, and fatty acids profile.
\end{abstract}

\section{INTRODUCTION}

The consumption of fish has been linked to health benefits, a reduced risk of coronary heart disease, arterial hypertension, human breast cancer growth, inflammatory diseases, asthma and disorders of immune system (Uauy and Valenzuela, 2000).

With more than 30,000 known species, fish form the biggest group in the animal kingdom that is used for the production of animal-based foods. Only about 700 of these species are commercially fished and used for food production. Further, some 100 crustacean and 100 molluscan species (for example mussels, snails and cephalopods) are used as food for humans. The amount captured worldwide is registered annually by the Food and Agriculture Organization of the United Nations (Rehbein and Oehlenschläger, 2009).

World fisheries production, by capture and aquaculture reached 142 million tons at 2008, China came at the first order, where it annually produced 47.5 million tons represented about $33.45 \%$ of world production. Egypt came at the first order between Arab countries, where it produced about million ton annually ( $0.7 \%$ of world production). As for world 
aquaculture production of fish, Egypt came at $11^{\text {th }}$ order $(693$ thousands tons). While as world capture production, Egypt came at $40^{\text {th }}$ order (374 thousands tons) (FAO 2008).

Fish and other seafood are very important in covering a part of the protein demand for humans. In 2000 , food fish contributed $15.9 \%$ to the human diet on a worldwide basis (fish as a percentage of total animal protein intake). There are, however, great differences between continents and countries. In low-income, food-deficient countries (LIFDC) fish contributes $20.6 \%$, in Asia 23.3\%, in China 21.1\%, whereas in South America the contribution amounts only to $5.7 \%$, in North and Central America to $7.1 \%$ and in Europe to $10.3 \%$. The average contribution in developed countries is $12 \%$ whereas it is $18.8 \%$ in developing countries (FAO, 2004).

Fish lipids differ from those of terrestrial animals mainly in their high content of long chain, highly unsaturated fatty acids of the n-3 series (eicosapentaenoic acid, 20:5 and docosahexaenoic acid, 22:6), often referred to as polyunsaturated fatty acids (PUFAs). The content of these PUFAs in fatty fish species can be high: dogfish $3 \mathrm{~g} / 100 \mathrm{~g}$, herring $2.3 \mathrm{~g} / 100 \mathrm{~g}$, mackerel $4.6 \mathrm{~g} / 100 \mathrm{~g}$, salmon $2.3 \mathrm{~g} / 100 \mathrm{~g}$ and tuna $2.1 \mathrm{~g} / 100 \mathrm{~g}$. The highly unsaturated character of these fatty acids is the reason why they are susceptible to lipid oxidation and oxidative degradation. Fatty fish species therefore have a tendency to exhibit rancid tastes and odours after limited storage time (Rehbein and Oehlenschläger, 2009).

Gokoglu et al. (2004) studied the effects of different cooking methods (frying, boiling, baking, grilling, microwave cooking) on proximate composition and mineral contents of rainbow trout (Oncorhynchus mykiss Walbaum 1792). They found that mean moisture, protein, ash and fat contents of raw fish were $73.38 \%, 19.8 \%, 1.35 \%$ and $3.44 \%$, respectively. The changes in dry matter, protein and ash contents were found to be significant for all cooking methods. The results indicated that cooking had considerable affect on the proximate composition and mineral contents. Baking and grilling were found to be the best cooking methods for healthy eating.

Saldanha and Bragagnolo (2008) studied the effect of different types of packing during frozen storage of Atlantic hake fillets and subsequent grilling on lipid composition and cholesterol oxidation. They found that the moisture levels and amount of lipids decreased after grilling and there was a significant decrease in the content of polyunsaturated fatty acids in all hake samples.

So, this study was done to study the effect of traditional grilling process on gross chemical composition and fatty acids profiles, mainly omega-3 fatty acids (EPA and DHA), in the most common Egyptian fish namely Sardine, Tilapia and Mullet. 


\section{MATERIALS AND METHODS}

\section{Materials:}

The most common Egyptian fish, Sardine (Sardinella aurita, Valenciennes, 1847), Grey Mullet (Mugil cephalus, Linnaeus, 1758) and Nile Tilapia (Oreochromis niloticus niloticus, Linnaeus, 1758) were purchased from fish local market, Damietta city, Egypt during October 2010. The fish weight means were 65,145 and $200 \mathrm{~g}$, respectively.

\section{Methods:}

\section{Grilling process:}

Each sample of fresh fish was washed with tap water several times to remove slime and then were coating with wood dust and grilled on hot plate for $20 \mathrm{~min}$. as a traditional grilling method.

After this traditional grill, grilled fish were cooled at room temperature. Then raw and grilled fish samples were filleted to produces fish flesh only (edible portions), homogenized using a kitchen blender to produce a representative samples and chemically analyzed.

\section{Chemical analysis:}

Moisture, ash, crude protein and crude oil contents were determined according to the method described by $A O A C$ (1990). Crude oil was extracted according to Bligh and Dyer (1959).

Fatty acids composition of fish fat samples were analyzed out in The Central Laboratory Unit, High Institute of Public Health, Alexandria University, Egypt. Fatty acid methyl esters were prepared according to the procedure of Radwan (1978). The different fatty acid methyl esters (FAMEs) were determined an identified using a gas chromatography (HP 6890) equipped with a flame ionization detector (FID). A HP-5 column (30 m) [5\% dimethyl $95 \%$ diphenyl polysiloxane] was used. The detector and injector temperatures were $250^{\circ} \mathrm{C}$ and $220^{\circ} \mathrm{C}$, respectively. Sample size was $1 \mu \mathrm{l}$. Helium was used as a carrier gas at a flow rate of $0.8 \mathrm{ml} / \mathrm{min}$. Oven temperature was programmed as:

- set point (initial temperature) $150^{\circ} \mathrm{C}$ for $1 \mathrm{Min}$

- rate $10^{\circ} \mathrm{C} / \mathrm{Min}$. to $200^{\circ} \mathrm{C}$.

- rate $5^{\circ} \mathrm{C} / \mathrm{Min}$. to $250^{\circ} \mathrm{C}$ and hold for $4 \mathrm{Min}$.

A standard mixture of methyl esters was used.

\section{RESULTS AND DISCUSSION}

Gross chemical composition of studied raw and grilled fish samples are in Table (1). From these results, it could be noticed that grilling process reduced moisture content in all fish samples under investigation. For example, moisture content of sardine fish decreased from $72.80 \%$ to $66.10 \%$ as affected by grilling process with a decrease of $9.20 \%$. Also, it could be reported that moisture content of Tilapia fish was the highest in both raw and grilled form $(76.75 \%$ and $69.90 \%$, respectively). 
El-Shehawy, Sh. M. et al.

Table (1): Effect of grilling process on chemical composition of the most common Egyptian fish:

\begin{tabular}{|c|c|c|c|c|c|c|c|c|}
\hline \multicolumn{2}{|c|}{ Component } & \multirow{2}{*}{ oisture \% } & \multicolumn{2}{c|}{ Ash \% } & \multicolumn{2}{c|}{ Crude oil \% } & \multicolumn{2}{c|}{ Crude protein \% } \\
\cline { 4 - 9 } & & $\boldsymbol{w} \boldsymbol{w}$ & $\boldsymbol{d w}$ & $\boldsymbol{w w}$ & $\boldsymbol{d} \boldsymbol{w}$ & $\boldsymbol{w} \boldsymbol{w}$ & $\boldsymbol{d} \boldsymbol{w}$ \\
\hline \multirow{2}{*}{ Fish samples } & Raw & 72.80 & 2.95 & 10.88 & 1.08 & 4.00 & 23.59 & 86.71 \\
\hline \multirow{2}{*}{ Mullet } & Grilled & 66.10 & 2.20 & 6.50 & 1.14 & 3.37 & 30.56 & 90.15 \\
\cline { 4 - 9 } & Raw & 68.35 & 2.80 & 8.87 & 7.00 & 22.14 & 21.85 & 69.04 \\
\cline { 2 - 9 } & Grilled & 66.05 & 1.27 & 3.77 & 3.87 & 11.40 & 29.44 & 86.71 \\
\hline \multirow{2}{*}{ Tilapia } & Raw & 76.75 & 1.90 & 8.24 & 2.81 & 12.1 & 18.32 & 78.80 \\
\cline { 2 - 9 } & Grilled & 69.90 & 0.69 & 2.32 & 1.00 & 3.33 & 28.41 & 94.39 \\
\hline
\end{tabular}

(ww) means wet weight and( dw) means dry weight.

These previous results concerning to moisture content could be explained that the high temperature used during grilling process helps to evaporate water from fish tissues. The loss of moisture during grilling is time, heating temperature, size and thickness of the fillets dependent.

As for ash content, it could be seen that ash content decreased a affected by grilling process, where it decreased from $8.87 \%$ to $3.77 \%$ ( $d w$ basis) in mullet fish with a decrease of $57.50 \%$. Raw sardine fish had the highest ash content on dry weight basis which it was $10.88 \%$. These decreases in ash could be due to some minerals diffusion from fish tissues.

Crude oil content decreased after grilling process in all fish samples, where it decreased from $22.14 \%$ to $11.40 \%$ ( $d w$ basis) with a decrease of $48.51 \%$ in mullet fish, which represented the highest crude oil content between the three fish samples. These decreases in crude oil content may be due to the high temperature used in grilling process and the low melting point of such fish oil and this explanation will be very clear during fatty acids composition discussion. These findings were in agreement with results obtained by Gokoglu et al. (2004) and Saldanha and Bragagnlo, (2008).

There is consensus that during grilling a loss in oil occurs due to dripping, although the amount lost depends on the temperature and time of grilling (Saldanha and Bragagnlo, 2008).

However, the lipid components of fish can vary according to the month of capture, the season and the particular area of sea (Ga'mez-Meza et al., 1999).

Finally, crude protein content of all fish samples increased as a results of grilling process. Crude protein of Tilapia fish increased from $78.80 \%$ to $94.39 \%$ ( $d w$ basis) after grilling process with an increase of $19.78 \%$, but in Sardine and Tilapia the increase percentage was 3.96\%and $25.6 \%$, respectively. These increases in crude protein ratios could be explained as all nutrients reduction such as moisture, ash and crude oil lead to crude protein increase.

These results were in a good agreement with those obtained by Saldanha and Bragagnlo (2008) and Me'ndez and Gonza'lez (1997).

Fatty acids composition of Sardine fish flesh as affected by grilling process was illustrated at Table (2). From these results, it could be reported that grilling process reduced saturated fatty acids percentage, where it decreased from $30.82 \%$ to $29.51 \%$ representing $-4.25 \%$ as a change percentage. Palmitic acid $\left(\mathrm{C}_{16: 0}\right)$ and stearic acid $\left(\mathrm{C}_{18: 0}\right)$ were the most predominant of saturated fatty acids, where they were $23.877 \%$ and $5.236 \%$ 
in raw Sardine fish, respectively. Palmitic acid decreased by $6.5 \%$ and stearic acid increased by $5.1 \%$ after grilling process.

Table (2): Effect of grilling process on fatty acids composition of Sardine fish flesh:

\begin{tabular}{|c|c|c|c|c|c|c|}
\hline \multirow{2}{*}{ Fatty acids } & \multicolumn{2}{|c|}{$\mathrm{g} / 100 \mathrm{~g}$ oil } & \multirow{2}{*}{ Change \% } & \multicolumn{2}{|c|}{$\%$ of total fatty acid } & \multirow{2}{*}{ Change \% } \\
\hline & Raw & Grilled & & Raw & Grilled & \\
\hline $\mathbf{C}_{6: 0}$ & 0.044 & 0.066 & 50.0 & 0.036 & 0.051 & 41.67 \\
\hline $\mathbf{C}_{8: 0}$ & 0.029 & 0.033 & 13.8 & 0.023 & 0.025 & 8.70 \\
\hline $\mathbf{C}_{10: 0}$ & 0.097 & 0.028 & -71.1 & 0.077 & 0.022 & -71.43 \\
\hline $\mathbf{C}_{12: 0}$ & 0.165 & 0.119 & -27.9 & 0.132 & 0.092 & -30.30 \\
\hline $\mathbf{C}_{13: 0}$ & 0.036 & 0.022 & -38.9 & 0.029 & 0.017 & -41.38 \\
\hline $\mathbf{C}_{14: 0}$ & 0.069 & 0.046 & -33.3 & 0.055 & 0.036 & -34.55 \\
\hline $\mathbf{C}_{15: 0}$ & 0.763 & 0.727 & -4.7 & 0.610 & 0.560 & -8.20 \\
\hline $\mathbf{C}_{16: 0}$ & 29.887 & 28.985 & -3.0 & 23.877 & 22.326 & -6.50 \\
\hline $\mathbf{C}_{17: 0}$ & 0.497 & 0.560 & 12.7 & 0.397 & 0.431 & 8.56 \\
\hline $\mathbf{C}_{18: 0}$ & 6.554 & 7.145 & 9.0 & 5.236 & 5.503 & 5.10 \\
\hline $\mathrm{C}_{20: 0}$ & 0.400 & 0.481 & 20.3 & 0.320 & 0.371 & 15.94 \\
\hline $\mathbf{C}_{21: 0}$ & 0.039 & 0.039 & 0.0 & 0.031 & 0.030 & -3.23 \\
\hline $\mathrm{C}_{22: 0}$ & 0.000 & 0.063 & - & 0.000 & 0.049 & - \\
\hline$\Sigma$ (Saturated) & 38.58 & 38.31 & -0.7 & 30.82 & 29.51 & -4.25 \\
\hline $\mathbf{C}_{14: 1}$ & 0.163 & 0.105 & -35.6 & 0.130 & 0.081 & -37.69 \\
\hline $\mathbf{C}_{15: 1}$ & 0.071 & 0.018 & -74.6 & 0.057 & 0.014 & -75.44 \\
\hline $\mathbf{C}_{16: 1 \omega-7}$ & 17.293 & 16.796 & -2.9 & 13.815 & 12.937 & -6.36 \\
\hline $\mathbf{C}_{17: 1}$ & 0.156 & 0.247 & 58.3 & 0.125 & 0.190 & 52.00 \\
\hline $\mathbf{C}_{18: 1 \omega-9}$ & 10.475 & 10.665 & 1.8 & 8.368 & 8.215 & -1.83 \\
\hline $\mathbf{C}_{20: 1 \omega-11+\omega-9}$ & 9.481 & 9.582 & 1.1 & 7.574 & 7.381 & -2.55 \\
\hline$C_{22: 1 \omega-11+\omega-9}$ & 0.701 & 0.823 & 17.4 & 0.560 & 0.634 & 13.21 \\
\hline$\Sigma$ (Monounsaturated) & 38.34 & 38.24 & -0.3 & 30.63 & 29.45 & -3.84 \\
\hline $\mathbf{C}_{18: 2 \omega-6}$ & 7.666 & 7.232 & -5.7 & 6.125 & 5.571 & -9.04 \\
\hline $\mathbf{C}_{18: 3 \omega-3}$ & 0.791 & 1.168 & 47.7 & 0.632 & 0.899 & 42.25 \\
\hline $\mathbf{C}_{20: 2 \omega-6}$ & 1.380 & 4.725 & 242.4 & 1.103 & 3.640 & 230.01 \\
\hline $\mathrm{C}_{20: 3 \omega-3}$ & 2.244 & 8.550 & 281.0 & 1.792 & 6.586 & 267.52 \\
\hline $\mathrm{C}_{20: 4 \omega-3}$ & 4.850 & 0.505 & -89.6 & 3.874 & 0.389 & -89.96 \\
\hline $\mathbf{C}_{20: 5 \omega-3}$ & 0.182 & 0.000 & -100.0 & 0.146 & 0.000 & -100.00 \\
\hline $\mathrm{C}_{22: 2}$ & 1.225 & 2.162 & 76.5 & 0.979 & 1.665 & 70.07 \\
\hline $\mathbf{C}_{22: 6 \omega-3}$ & 0.263 & 0.266 & 1.1 & 0.210 & 0.205 & -2.38 \\
\hline $\boldsymbol{\Sigma}$ (Polyunsaturated) & 18.60 & 24.61 & 32.3 & 14.86 & 18.96 & 27.55 \\
\hline Total unsaturated & 56.94 & 62.85 & 10.38 & 45.49 & 48.41 & 6.42 \\
\hline$\omega-3 / \omega-6$ & 0.92 & 0.88 & -4.66 & 0.92 & 0.88 & -4.66 \\
\hline Biological Value* & 1.48 & 1.64 & 9.76 & 1.48 & 1.64 & 9.76 \\
\hline
\end{tabular}

* Biological value means total unsaturated fatty acids / total saturated fatty acids.

As for monounsaturated fatty acids, it was constant and did not change as affected by grilling process. Monoenes was $30.63 \%$ and $29.45 \%$ in raw and grilled Sardine fish, respectively. $\left(\mathrm{C}_{16: 1}\right.$ w-7 $)$ was the highest monounsaturated fatty acid $(13.815 \%$ in raw and $12.937 \%$ in grilled), while oleic acid $\left(\mathrm{C}_{18: 1} \omega-9\right)$ was in the second order, where it represented $8.368 \%$ and $8.215 \%$ in both raw and grilled forms, respectively. Also, $\left(\mathrm{C}_{20: 1} \omega-11+\omega-9\right)$ was $7.574 \%$ and $7.381 \%$ in the same both forms.

Grilling process caused an increase in polyunsaturated fatty acids content due to the decrease in saturated fatty acid during grilling as shown in Table (2), where it increased from $14.86 \%$ in raw Sardine fish to $18.96 \%$ after grilling process. The most predominant polyunsaturated fatty acid was linoleic 
acid $\left(\mathrm{C}_{18: 2 \omega-6}\right)$, which represented $6.125 \%$ and $5.571 \%$ in raw and grilled fish, respectively. Egyptian raw and grilled Sardine fish was poor in omega-3 fatty acids especially ecosapentanoic acid (EPA) and decosahexanoic acid (DHA), where they were $0.146 \%$ and $0.210 \%$, respectively. Total unsaturated fatty acids content increased after grilling process, where it changed from $45.49 \%$ to $48.41 \%$. And consequently, total unsaturated fatty acids/ total saturated fatty acids ratio, biological value, (Dailel, 1964) of this oil increased by $9.76 \%$ as a change percentage. As omega-3/omega- 6 , it decreased by $4.66 \%$ as a change percentage after grilling process (Table 2).

The lipid components and contents of fish vary according to the species, age, location, species origin characteristics, such as spawning and migration seasons, and also some environmental conditions, such as temperature (Huss, 1988).

Fatty acids composition of Mullet fish flesh as affected by traditional grilling process is presented in Table (3).

Table (3): Effect of grilling process on fatty acids composition of Mullet fish flesh:

\begin{tabular}{|c|c|c|c|c|c|c|}
\hline \multirow{2}{*}{ Fatty acids } & \multicolumn{2}{|c|}{$\mathrm{g} / 100 \mathrm{~g}$ oil } & \multirow{2}{*}{ Change \% } & \multicolumn{2}{|c|}{$\%$ of total fatty acid } & \multirow{2}{*}{ Change \% } \\
\hline & Raw & Grilled & & Raw & Grilled & \\
\hline $\mathbf{C}_{6: 0}$ & 0.027 & 0.044 & 62.96 & 0.026 & 0.044 & 69.23 \\
\hline $\mathrm{C}_{8: 0}$ & 0.025 & 0.023 & -8.00 & 0.024 & 0.023 & -4.17 \\
\hline $\mathrm{C}_{10: 0}$ & 0.140 & 0.020 & -85.71 & 0.133 & 0.020 & -84.96 \\
\hline $\mathbf{C}_{12: 0}$ & 0.011 & 0.031 & 181.82 & 0.011 & 0.031 & 181.82 \\
\hline $\mathbf{C}_{13: 0}$ & 0.078 & 0.117 & 50.00 & 0.074 & 0.117 & 58.11 \\
\hline $\mathbf{C}_{14: 0}$ & 4.826 & 4.789 & -0.77 & 4.577 & 4.771 & 4.24 \\
\hline $\mathbf{C}_{15: 0}$ & 1.093 & 1.235 & 12.99 & 1.037 & 1.230 & 18.61 \\
\hline $\mathbf{C}_{16: 0}$ & 22.522 & 22.475 & -0.21 & 21.359 & 22.388 & 4.82 \\
\hline $\mathbf{C}_{17: 0}$ & 0.894 & 0.869 & -2.80 & 0.848 & 0.865 & 2.00 \\
\hline $\mathbf{C}_{18: 0}$ & 2.935 & 3.338 & 13.73 & 2.783 & 3.326 & 19.51 \\
\hline $\mathbf{C}_{20: 0}$ & 0.350 & 0.327 & -6.57 & 0.332 & 0.325 & -2.11 \\
\hline $\mathbf{C}_{21: 0}$ & 0.026 & 0.040 & 53.85 & 0.025 & 0.040 & 60.00 \\
\hline$\Sigma$ (Saturated) & 32.927 & 33.308 & 1.16 & 31.229 & 33.180 & 6.25 \\
\hline $\mathrm{C}_{14: 1}$ & 0.102 & 0.105 & 2.94 & 0.097 & 0.105 & 8.25 \\
\hline $\mathbf{C}_{15: 1}$ & 0.069 & 0.086 & 24.64 & 0.066 & 0.086 & 30.30 \\
\hline $\mathbf{C}_{16: 1 \omega-7}$ & 12.215 & 12.527 & 2.55 & 11.584 & 12.479 & 7.73 \\
\hline $\mathbf{C}_{17: 1}$ & 0.536 & 0.492 & -8.21 & 0.508 & 0.491 & -3.35 \\
\hline $\mathbf{C}_{18: 1 \omega-9}$ & 5.893 & 3.291 & -44.15 & 5.589 & 3.278 & -41.35 \\
\hline $\mathbf{C}_{20: 1 \omega-11+\omega-9}$ & 4.953 & 3.390 & -31.56 & 4.697 & 3.377 & -28.10 \\
\hline $\mathbf{C}_{22: 1 \omega-11+\omega-9}$ & 1.324 & 1.197 & -9.59 & 1.256 & 1.192 & -5.10 \\
\hline$\Sigma$ (Monounsaturated) & 25.092 & 21.088 & -15.96 & 23.797 & 21.008 & -11.72 \\
\hline $\mathrm{C}_{18: 2 \omega-6}$ & 25.226 & 23.310 & -7.60 & 23.924 & 23.220 & -2.94 \\
\hline $\mathbf{C}_{18: 3 \omega-3}$ & 1.256 & 0.982 & -21.82 & 1.192 & 0.978 & -17.95 \\
\hline $\mathbf{C}_{20: 2 \omega-6}$ & 2.881 & 2.203 & -23.53 & 2.732 & 2.195 & -19.66 \\
\hline $\mathbf{C}_{20: 3 \omega-3}$ & 1.460 & 2.361 & 61.71 & 1.385 & 2.352 & 69.82 \\
\hline $\mathbf{C}_{20: 4 \omega-3}$ & 1.289 & 1.885 & 46.24 & 1.223 & 1.878 & 53.56 \\
\hline $\mathbf{C}_{20: 5 \omega-3}$ & 0.135 & 0.329 & 143.70 & 0.128 & 0.328 & 156.25 \\
\hline $\mathrm{C}_{22: 2}$ & 1.041 & 1.353 & 29.97 & 0.987 & 1.348 & 36.58 \\
\hline $\mathbf{C}_{22: 6 \omega-3}$ & 0.195 & 0.205 & 5.13 & 0.185 & 0.204 & 10.27 \\
\hline$\Sigma($ Polyunsaturated) & 33.483 & 32.628 & -2.55 & 31.756 & 32.503 & 2.35 \\
\hline Total unsaturated & 58.575 & 53.716 & -8.30 & 55.553 & 53.511 & -3.68 \\
\hline$\omega-3 / \omega-6$ & 0.154 & 0.226 & 46.75 & 0.154 & 0.226 & 46.75 \\
\hline Biological Value* & 1.78 & 1.61 & -9.55 & 1.78 & 1.61 & -9.55 \\
\hline
\end{tabular}

* Biological value means total unsaturated fatty acids / total saturated fatty acids. 
Palmitic acid $\left(\mathrm{C}_{16: 0}\right)$ was the main saturated fatty acid in raw Mullet fish, where it was $21.359 \%$ and reached $22.388 \%$ after grilling with an increase of $4.82 \%$. Myristic acid $\left(\mathrm{C}_{14: 0}\right)$ came in the second order between saturated fatty acids. It increased after grilling process with an increase of $4.82 \%$. Stearic acid $\left(\mathrm{C}_{18: 0}\right)$ came in the third order, where it was $2.783 \%$ and $3.326 \%$ in raw and grilled Mullet fish, respectively. So, total saturated fatty acids content increased after grilling process, where it changed from $31.229 \%$ to $33.180 \%$ with an increases of $6.25 \%$ (Table 3 ).

As monounsaturated fatty acids, monoenes decreased from $23.797 \%$ in raw Mullet fish form to $21.008 \%$ in grilled form with a decrease of $11.72 \%$. $\left(C_{16: 1} \omega_{-7}\right)$ came in the first order, where it was $11.584 \%$ and $12.479 \%$ in raw and grilled Mullet fish form, respectively. While oleic acid ( $\left.C_{18: 1} \omega-9\right)$ came in the second order. It decreased as affected by grilling process with decrease of $41.35 \%$. Also, $\mathrm{C}_{20: 1} \omega-11+\omega-9$ had clear value which represented $4.697 \%$ and $3.377 \%$ in raw and grilled Mullet fish form, respectively (Table 3).

Finally, polyunsaturated fatty acids increased from $31.756 \%$ to $32.503 \%$ as affected by grilling process. Linoleic acid $\left(\mathrm{C}_{18: 2} \omega-6\right)$ was the main polyunsaturated fatty acid. It represented $23.924 \%$ and $23.220 \%$ in raw and grilled Mullet fish, respectively. While EPA and DHA were very low in Mullet fish. EPA was $0.128 \%$ and $0.328 \%$ in raw and grilled Mullet fish, respectively. DHA was $0.185 \%$ in raw fish and $0.204 \%$ in grilled Mullet fish.

So, total unsaturated fatty acids content decreased from $55.553 \%$ in raw Mullet fish to $53.511 \%$ in grilled Mullet fish with a decrease of $3.68 \%$. Subsequently, biological value (Dailel, 1964) decreased also with a decrease of $9.55 \%$. $\omega-3 / \omega-6$ ratio was very small, where it was 0.226 in grilled Mullet fish. These results were in a good agreement with those obtained by Saldanha and Bragagnlo (2008).

Other authors reported a decrease of $\omega-3 / \omega-6$ during different heat treatments of fish samples (Gladyshev et al., 2006 and Gladyshev et al., 2007).

Fatty acids composition of Tilapia fish flesh as affected by traditional grilling process is presented in Table (4). Total saturated fatty acids content decreased from $33.347 \%$ to $32.563 \%$ as affected by grilling process. Palmitic acid $\left(C_{16: 0}\right)$ was the main saturated fatty acid, where it was $22.194 \%$ in raw Tilapia fish flesh.

Stearic acid $\left(\mathrm{C}_{18: 0}\right)$ came in the second order of saturated fatty acids. It increased by $11.18 \%$ after grilling process. While, myristic acid $\left(C_{14: 0}\right)$ came in the third order, where it decreased from $4.086 \%$ to $3.365 \%$ after grilling.

As for monounsaturated fatty acid content, it was $17.838 \%$ and $18.284 \%$ in raw and grilled Tilapia fish flesh, respectively. Oleic acid came in the first order of monoenes, where it was $9.362 \%$ and $10.213 \%$ in raw and grilled Tilapia, respectively. $\mathrm{C}_{16: 1} \omega-7$ came in the second order, its content decreased from $5.660 \%$ to $5.176 \%$ as affected by grilling process. $\mathrm{C}_{20: 1} \omega-11+$ $\omega-9$ increased from $1.875 \%$ to $2.078 \%$ after grilling process (Table 4).

Form the same Table it is noticeable that, Linoleic acid $\left(\mathrm{C}_{18: 2} \omega-6\right)$ came in the first order of polyunsaturated fatty acids. Its content reached $37.633 \%$ in raw form and $38.000 \%$ in grilled form with increase of $0.98 \%$. 
While, omega-3 fatty acids (EPA and DHA) were very small amounts, did not exceed $1.0 \%$ and thus, there is no clear effect of grilling process.

Table (4): Effect of grilling process on fatty acids composition of Tilapia fish flesh:

\begin{tabular}{|c|c|c|c|c|c|c|}
\hline \multirow{2}{*}{ Fatty acids } & \multicolumn{2}{|c|}{$\mathrm{g} / 100 \mathrm{~g}$ oil } & \multirow{2}{*}{ Change \% } & \multicolumn{2}{|c|}{$\%$ of total fatty acid } & \multirow{2}{*}{ Change \% } \\
\hline & Raw & Grilled & & Raw & Grilled & \\
\hline $\mathbf{C}_{6: 0}$ & 0.109 & 0.055 & -49.54 & 0.096 & 0.044 & -54.17 \\
\hline $\mathbf{C}_{8: 0}$ & 0.020 & 0.024 & 20.00 & 0.018 & 0.019 & 5.56 \\
\hline $\mathbf{C}_{10: 0}$ & 0.036 & 0.020 & -44.44 & 0.032 & 0.016 & -50.00 \\
\hline $\mathrm{C}_{12: 0}$ & 0.449 & 0.008 & -98.22 & 0.397 & 0.006 & -98.49 \\
\hline $\mathbf{C}_{13: 0}$ & 0.040 & 0.036 & -10.00 & 0.035 & 0.029 & -17.14 \\
\hline $\mathbf{C}_{14: 0}$ & 4.618 & 4.188 & -9.31 & 4.086 & 3.365 & -17.65 \\
\hline $\mathbf{C}_{15: 0}$ & 0.540 & 0.540 & 0.00 & 0.477 & 0.434 & -9.01 \\
\hline $\mathbf{C}_{16: 0}$ & 25.083 & 27.582 & 9.96 & 22.194 & 22.165 & -0.13 \\
\hline $\mathbf{C}_{17: 0}$ & 0.629 & 0.642 & 2.07 & 0.557 & 0.516 & -7.36 \\
\hline $\mathbf{C}_{18: 0}$ & 5.548 & 6.792 & 22.42 & 4.909 & 5.458 & 11.18 \\
\hline $\mathbf{C}_{20: 0}$ & 0.431 & 0.438 & 1.62 & 0.381 & 0.352 & -7.61 \\
\hline $\mathbf{C}_{21: 0}$ & 0.187 & 0.199 & 6.42 & 0.165 & 0.159 & -3.64 \\
\hline$\Sigma$ (Saturated) & 37.690 & 40.524 & 7.52 & 33.347 & 32.563 & -2.35 \\
\hline $\mathbf{C}_{14: 1}$ & 0.157 & 0.139 & -11.46 & 0.139 & 0.112 & -19.42 \\
\hline $\mathbf{C}_{15: 1}$ & 0.053 & 0.070 & 32.08 & 0.046 & 0.056 & 21.74 \\
\hline $\mathbf{C}_{16: 1 \omega-7}$ & 6.397 & 6.441 & 0.69 & 5.660 & 5.176 & -8.55 \\
\hline $\mathbf{C}_{17: 1}$ & 0.506 & 0.473 & -6.52 & 0.448 & 0.380 & -15.18 \\
\hline $\mathbf{C}_{18: 1 \omega-9}$ & 10.581 & 12.709 & 20.11 & 9.362 & 10.213 & 9.09 \\
\hline $\mathrm{C}_{20: 1 \omega-11+\omega-9}$ & 2.010 & 2.586 & 28.66 & 1.857 & 2.078 & 11.90 \\
\hline $\mathbf{C}_{22: 1 \omega-11+\omega-9}$ & 0.369 & 0.334 & -9.49 & 0.326 & 0.269 & -17.48 \\
\hline$\Sigma$ (Monounsaturated) & 20.073 & 22.752 & 13.35 & 17.838 & 18.284 & 2.50 \\
\hline $\mathbf{C}_{18: 2 \omega-6}$ & 42.532 & 47.300 & 11.21 & 37.633 & 38.000 & 0.98 \\
\hline $\mathbf{C}_{18: 3 \omega-3}$ & 0.154 & 0.194 & 25.97 & 0.136 & 0.156 & 14.71 \\
\hline $\mathbf{C}_{20: 2 \omega-6}$ & 0.747 & 0.888 & 18.88 & 0.661 & 0.713 & 7.87 \\
\hline $\mathbf{C}_{20: 3 \omega-3}$ & 0.457 & 0.523 & 14.44 & 0.405 & 0.421 & 3.95 \\
\hline $\mathbf{C}_{20: 4 \omega-3}$ & 0.297 & 0.381 & 28.28 & 0.263 & 0.306 & 16.35 \\
\hline $\mathbf{C}_{20: 5 \omega-3}$ & 0.331 & 0.426 & 28.70 & 0.293 & 0.342 & 16.72 \\
\hline $\mathrm{C}_{22: 2}$ & 0.883 & 1.019 & 15.40 & 0.782 & 0.819 & 4.73 \\
\hline $\mathbf{C}_{22: 6 \omega-3}$ & 0.190 & 0.203 & 6.84 & 0.168 & 0.163 & -2.98 \\
\hline$\Sigma($ Polyunsaturated) & 45.591 & 50.934 & 11.72 & 40.341 & 40.920 & 1.44 \\
\hline Total unsaturated & 65.664 & 73.686 & 12.22 & 58.179 & 59.204 & 1.76 \\
\hline$\omega-3 / \omega-6$ & 0.033 & 0.036 & 9.09 & 0.033 & 0.036 & 9.09 \\
\hline Biological Value* & 1.74 & 1.82 & 4.60 & 1.74 & 1.82 & 4.60 \\
\hline
\end{tabular}

Total polyunsaturated fatty acids recorded about $40 \%$ and did not change as affected by grilling process. Subsequently, total unsaturated fatty acids reached $58.179 \%$ and $59.204 \%$ in raw and grilled Tilapia fish flesh, respectively. Biological value of Tilapia oil increased as affected by grilling process with increase of $4.6 \%$.

$\omega-3 / \omega-6$ ratio was very small and this indicted that Tilapia oil could not be considered a source of omega-3 fatty acids. However, Al-Saghir et al.(2004) observed that $\omega-3 / \omega-6$ ratio remained constant after frying of Salmon fillets in olive oil.

Finally, a comparison between fatty acids composition of the previous studied fish oils should be in consideration. From results in Tables (2, 3 and 
4), it easily could be concluded that palmitic $\left(\mathrm{C}_{16: 0}\right)$ acid was the main saturated fatty acid in the three studied fish samples. It reached $23.877 \%$, $21.359 \%$ and $22.194 \%$ in raw Sardine, Mullet and Tilapia, respectively. Palmitic acid remained constant in grilled Tilapia, but it decreased by $6.50 \%$ in grilled Sardine and increased by $4.82 \%$ in grilled Mullet. It could b noticed that stearic $\left(\mathrm{C}_{18: 0}\right)$ acid recorded valuable content in raw Sardine and Tilapia (5.236\% and $4.909 \%$, respectively). Total saturated fatty acids in the three studied fish samples were more than $30 \%$. These ratios decreased in Sardine and Tilapia and increased in Mullet as affected by grilling process.

$\mathrm{C}_{16: 1} \mathrm{\omega}_{-7}$ fatty acid was reported as the main monounsaturated fatty acids in raw Sardine and Mullet, where it reached $13.815 \%$ and $11.584 \%$, respectively. While oleic acid was the main monoens in raw Tilapia $(9.362 \%)$. Total monounsaturated fatty acids content recorded the values of $30.36 \%$, $23.797 \%$ and $17.838 \%$ in raw Sardine, Mullet and Tilapia, respectively.

$\mathrm{C}_{18: 2} \omega-6$ linoleic acid was the main polyunsaturated fatty acid in the three fish samples. Linoleic acid content in raw Tilapia fish was the highest $(37.633 \%)$. And subsequently, polyunsaturated fatty acids content in raw Tilapia were the highest $(40.341 \%)$, while raw Sardine fish had the least content $(14.86 \%)$. Grilling process caused an increase of polyunsaturated fatty acids content in all fish samples.

\section{CONCLUSION}

From previous results, it could be reported that the most common Egyptian fish contained low contents of necessary fatty acids especially omega-3 fatty acids (EPA and DHA). This note may be due to the month of capture, the season and some environmental conditions. Also, grilling process affected on fatty acids composition of the most common Egyptian fish in different manner according to fish type and thickness. So, it is recommended to increase consumption of other types of fish which are rich in these fatty acids.

\section{REFERENCES}

Al-Saghir, S.; Thurner, K.; Wagner, K. H.; Frisch, G.; Luf, W. and RezzaziFazeli, E. (2004). Effects of different cooking procedures on lipid quality and cholesterol oxidation of farmed salmon fish (Salmo solar). Journal of Agriculture and Food Chemistry, 52: 5290-5296.

AOAC (1990). Official Methods of Analysis, 15 th Ed. Association of Official Analytical Chemists, Arlington, Virginia, USA.

Bligh, E. and Dyer, W. (1959). A rapid method of total lipid extraction and purification. Canadian Journal of Biochemistry and Physiology, 37: 911-917.

Dailel,A.E(1964). Bailey's Industrial Oils and Fat Products. Interscience publishers. New York. 
FAO (2004). The State Of World Fisheries and Aquaculture - SOFIA 2004. http://www.fao.org ftp://ftp.fao.org/docrep/fao/007/y5600e/y5600e00.pdf

FAO (2008). Food and Agriculture Organization of the United Nations, Fisheries Department Statistical Databases and software, Yearbooks of Fishery Statistics Summary tables. http://www.fao.org ftp://ftp.fao.org/fi/stat/summary/default.htm

Ga'mez-Meza, N.; Higuera-Ciapara, I.; de La Barca, A. M. C.; Va'zquezMoreno, L.; Noriega-Rodriguez, J. A. and Angulo-Guerrero, O. (1999). Seasonal variation in the fatty acid composition and quality of sardine oil from Sardinops sagax caeruleus of the Gulf of California. Lipids, 34: 639-642.

Gladyshev, M. I.; Sushchik, N.N.; Gubanenko, G. A.; Demirchieva, S. M. and Kalachova, G. S. (2006). Effect of way of cooking on content of essential polyunsaturated fatty acids in muscle tissue of humpback salmon (Onchorhynchus gorbuscha). Food Chemistry, 96, (3): 446451.

Gladyshev, M. I.; Sushchik, N.N.; Gubanenko, G. A.; Demirchieva, S. M. and Kalachova, G. S. (2007). Effect of boiling and frying on the content of essential polyunsaturated fatty acids in muscle tissue of four fish species. Food Chemistry, 101, (4): 1694-1700.

Gokoglu, N.; Yerlikaya, P. and Cengiz, E. (2004). Effects of cooking methods on the proximate composition and mineral contents of rainbow trout (Oncorhynchus mykiss). Food Chemistry 84: 19-22.

Huss, H. H. (1988). Fresh fish quality and quality changes. Roma, Italy: FAO.

Me'ndez, E. and Gonza'lez, R. M. (1997). Seasonal changes in the chemical and lipid composition of fillets of the Southwest Atlantic hake (Merluccius hubbsi). Food Chemistry, 59: 213-217.

Radwan, S.S. (1978). Coupling of two dimensional thin layer chromatography with gas chromatography for the quantitative analysis of lipid classes and their constituent fatty acids. J. Chromatog. Sci 16:538-542.

Rehbein, H. and Oehlenschläger, J. (2009). Fishery Products: Quality, Safety and Authenticity. Blackwell Publishing Ltd. UK.

Saldanha, T. and Bragagnolo, N. (2008). Relation between types of packaging, frozen storage and grilling on cholesterol and fatty acids oxidation in Atlantic hake fillets (Merluccius hubbsi). Food Chemistry, 106: 619-627.

Uauy, R. and Valenzuela, A. (2000). Marine Oils: The health benefits of $n-3$ fatty acids. Nutrition, 16: 680-684. 


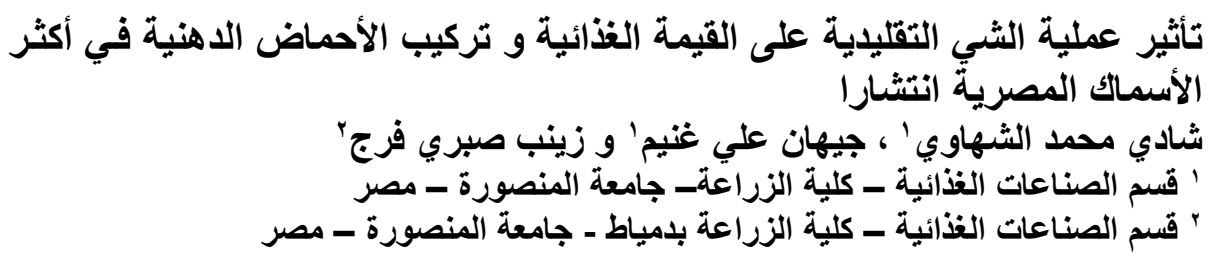

نم تنفيذ هذا البحث لدراسة تأثير علية الثي التقليدية على القيمة الغذائية و تركيب التئي

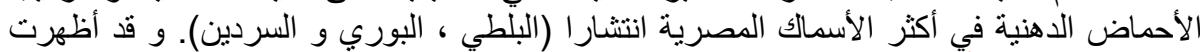

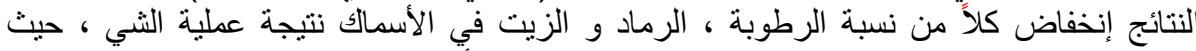

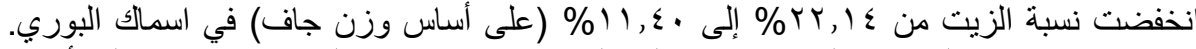

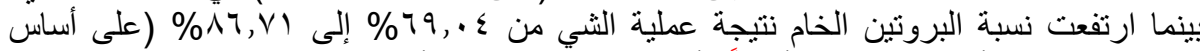

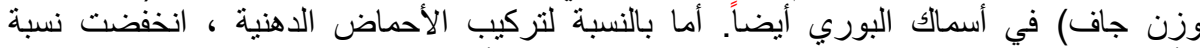

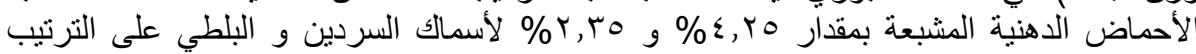

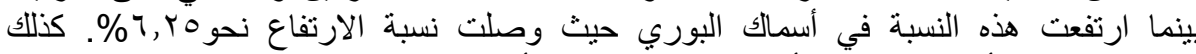

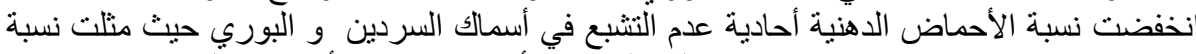

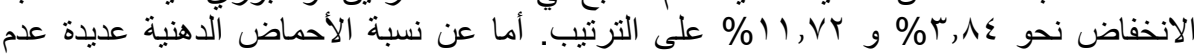

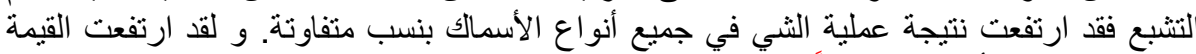

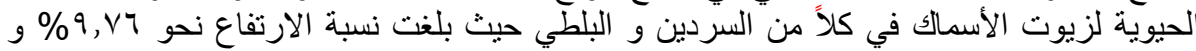

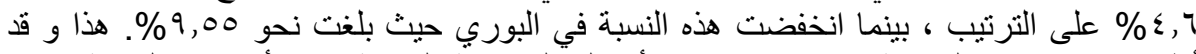

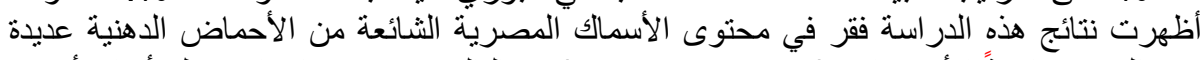

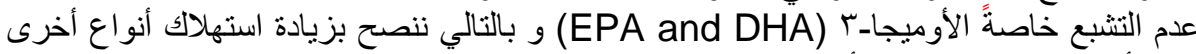

من الأسماك الغنية في هذه الأحماض الضراض الضرورية. الكلمات الدالة: شي الأسماك ـ التركيب الكيماوي ـ القيمة الغذائية ـ تركيب الأحماض الدهنية.

كلية الزراعة - جامعة المنصورة كلية الزراعة - جامعة القاهرة

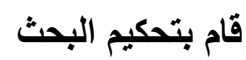

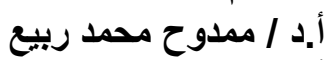

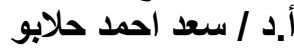

